\title{
Rekenaartegnologie - 'n brug tussen die Ou Testament en vandag
}

Aan die Stellenbosse Universiteit bestaan tans ' $n$ Navorsingseenheid wat op ' $n$ unieke wyse die moontlikhede van die moderne rekenaartegnologie inspan en benut in die interpretasie van die taal (Bybelse Hebreeus) en die teks van die Ou Testament.

Vir die bestudering van die tekskritiek is dit van belang om aandag te gee aan ander tale waarin die Ou Testament vertaal is, byvoorbeeld Grieks en Siries. Die hoeveelheid inligting waarmee die navorser vandag op dié gebiede te doen het, asook die kompleksiteit van die vraagstellings, maak dit daarom eintlik noodsaaklik om van die rekenaar as hulpmiddel gebruik te maak.

Die doelstellings van die Eenheid is:

1. Die skep van die nodige fasiliteite

Daar word gepoog om fasiliteite daar te stel om op 'n sinvolle en doeltreffende wyse van die rekenaar gebruik te maak by die bestudering van die taal en teks van die $\mathrm{Ou}$ Testament (asook die taal en teks van die vroeë vertalings van die Ou Testament). Hierdie fasiliteite behels onder andere

- die verkryging en inkodering van teksdata in rekenaarleesbare vorm,

- die opbou van databasisse om die teksdata doeltreffend te manipuleer,

- die skep van die nodige programmatuur en programmeringskundigheid vir toepassings van hierdie aard.

2. Die ontwikkeling van 'n nuwe generasie navorsingshulpmiddele

Daar word gepoog om 'n nuwe generasie navorsingshulpmiddele of 'gereedskap/implimente' te ontwikkel om die taal- en tekskritiese gegewens van die Ou Testament doeltreffend te hanteer op alle vlakke van die navorsing (bv. konkordansies, interaktiewe stelsels, ens.). 


\section{Navorsing}

Navorsing, met gebruikmaking van hierdie fasiliteite en implimente, kan onderneem word ten opsigte van spesifieke aspekte van die Hebreeuse grammatika en die tekskritiek van die Ou Testament.

4. Die daarstel van 'n toekomstige kritiese uitgawe van die Hebreeuse Ou Testament

Hierdie hulpmiddels sal ook benut word om 'n konstruktiewe bydrae te lewer tot 'n toekomstige kritiese uitgawe van die Hebreeuse Ou Testament, waarin die resultate van tekskritiese navorsing op 'n meer verantwoordbare wyse verwerk is.

\section{Opleiding van nagraadse studente}

Nagraadse studente moet effektief opgelei word sodat hulle doeltreffend gebruik kan maak van 'n nuwe generasie navorsingshulpmiddele by die bestudering van die taal en teks van die Ou Testament.

Dit het intussen duidelik geword dat die Eenheid in die uitvoering van hierdie doelstellings ook aandag sal moet gee aan materiaal wat elders ontwikkel word en op die akademiese toneel beskikbaar raak. Hierdie produkte moet geëvalueer word uit die oogpunt van die gehalte en bruikbaarheid daarvan, asook in terme van die rekenaarmatige/inligtingkundige hantering van die materiaal en die hermeneutiese uitgangspunte wat daardeur veronderstel word.

Die resultaat en produkte van die navorsing vind neerslag in wetenskaplike artikels, navorsingsverslae, referate, naslaanwerke, rekenaarprogramme en elektroniese databasisse. Die produkte van die navorsing wat in die Eenheid onderneem word, is nie net van belang vir die werk van navorsers op dié spesifieke gebiede nie, maar ook op die gebied van die teologie, veral die eksegese.

Hierdie Navorsingseenheid is gesetel in die Departement Semitiese Tale en Kulture aan die Universiteit van Stellenbosch. Die direkteur van die Eenheid is prof. W.T. Claassen.

Navrae: Dept. Semitiese Tale en Kulture, Universiteit van Stellenbosch.

Tel. (02231) 773205 